\title{
1. The Sex Discrimination Act and its Rocky Rite of Passage
}

\author{
Margaret Thornton and Trish Luker
}

Through an analysis of the parliamentary debates on the Sex Discrimination Bill 1983-84, this chapter underscores the anxiety that preoccupied the opponents of the Bill. Their fear that the Bill would give rise to a totalitarian regime, reminiscent of an Eastern bloc country, is clearly apparent from their own words. Not only would the passage of the Bill signal a blow to democracy, it would result in the creation of a unisex society and, most significantly, the demise of the nuclear family.

\section{Introduction}

Will the Prime Minister give an assurance to Australian women that neither the Government's proposed sex discrimination Bill nor ratification of the United Nations Convention on the Elimination of All Forms of Discrimination Against Women will in any way discriminate against women who choose life within the family, will not force them to go out to work, separate them from their children or break up their families, as some people have recently been suggesting? ${ }^{1}$

The passage of the Sex Discrimination Act 1984 (Cth) (SDA) represents a high political moment in the history of gender relations in Australia. The seemingly protracted debates of $1983-84^{2}$ were marked by a deep anxiety about sex roles, the patriarchal family and the wellbeing of children. The hysterical propaganda campaign and the fear engendered by the Bill were out of all proportion to its modest liberal intent that women be 'let in' to certain domains of public and quasi-public life, including employment, on the same terms as men.

Reliance on the external affairs power (Constitution, s. 51 [xxix]) to implement legislation in the absence of an express head of power had only recently been

\footnotetext{
1 Mrs Elaine Darling, Member for Lilley (ALP), Question without notice, House Hansard, 10 May 1983, p. 349.

2 Sawer debunks the myth that the debate on the Sex Discrimination Bill was 'the longest in the Australian Parliament'. In fact, it was only the eleventh longest, involving 17 hours of debate, compared with almost 70 hours on the two Communist Party Dissolution Bills. See Marian Sawer with Gail Radford, Making Women Count: A History of the Women's Electoral Lobby in Australia, UNSW Press, Sydney, 2008, p. 184.
} 
held to be constitutional by the High Court. ${ }^{3}$ The relevant international treaty on which the SDA was based was the UN Convention on the Elimination of All Forms of Discrimination Against Women (CEDAW). For some parliamentarians, recourse to an international treaty as the constitutional basis of domestic law represented not only a derogation of Australian sovereignty, but also a backdoor mechanism for augmenting federal power at the expense of the States, ${ }^{4}$ thereby fanning the residual resentment regarding the attempts by the Whitlam Government to modernise the Australian nation-state. ${ }^{5}$ It is nevertheless apparent that more than constitutionality was at stake. Not only was the shadow of the Cold War discernible in the denunciation of CEDAW as a communist plot, but, by a convenient sleight of hand, the misogyny underpinning opposition to the Bill became imbricated with the bogeys of totalitarianism, including the suggestion that children would be confined to drab childcare centres while their mothers entered forced labour camps. The suspicion of UN member states that did not espouse Western liberal-democratic capitalism also evinced a deep ethnocentrism and fear of the Other.

The question of whether law can change hearts and minds in the face of intransigent opposition remains an enigma. It encouraged us to revisit the debates on the SDA in 2009 - the year of its silver anniversary-because similar issues are on the agenda once more as we contemplate the National Human Rights Consultation Report (Brennan Report), ${ }^{6}$ the key recommendation of which is that a federal Human Rights Act be enacted. It is already clear that such an Act would be highly contentious, not only because it would depend for its validity on seven international treaties, including CEDAW, but because it would also include a wide-ranging equality prescript - an idea that continues to be viewed as destabilising by conservatives, particularly in the case of sex and sexuality. Indeed, any suggestion of legislating for human rights is being trenchantly opposed by right-wing Christian lobby groups even before a bill has been tabled. ${ }^{7}$ Objections are couched in terms of freedom of conscience and opposition to vesting judges with 'unfettered discretion'. It is notable that an

\footnotetext{
3 Koowarta v Bjelke-Petersen (1982) 153 CLR 168 (Koowarta); Commonwealth v Tasmania (1983) 158 CLR 1 (Tasmanian Dams). Koowarta upheld the validity of Racial Discrimination Act 1975 (Cth), which was based on the Convention on the Elimination of All Forms of Racial Discrimination.

4 Queensland Senator Boswell (NP) alleged that the government was using 'a United Nations treaty to come in right over the top of the States...taking sovereignty away from the States of Australia' (Senate Hansard, 29 November 1983, p. 2963). Senator Walters (LP) claimed that the Hawke Government had 'altered the Constitution by the backdoor method' by trying to 'take over the rights of one of the small States' - namely, her state of Tasmania (Senate Hansard, 16 December 1983, p. 3959). See also Senator Crichton-Browne (LP), Senate Hansard, 16 December 1983, p. 3960.

5 See, for example, Commonwealth v Queensland (1975) 134 CLR 298 (Queen of Queensland Case).

6 Commonwealth of Australia, National Human Rights Consultation Report, Commonwealth of Australia, Canberra, 2009 [Brennan Report].

7 For example, Patrick Parkinson, Christian concerns with the charter of rights, Paper presented at Cultural and Religious Freedom under a Bill of Rights Conference, Canberra, 2009.
} 
attempt to effect an amendment to the $S D A$ in 1983 to include an exception on the ground of freedom of conscience (to discriminate) was rejected in the course of the debates.

Even though there is no established church in Australia and the most recent census figures reveal that 15.5 per cent of the population professes no religion, ${ }^{8}$ Christianity and religious values continue to play a central role in shaping gendered norms. These values, which are based on ancient texts, including the Bible, are often patriarchal and misogynistic, necessarily conflicting with the egalitarian secularism underpinning the legislation. This tension between secularism and religion is now being routinely played out in law. ${ }^{9}$ Accordingly, it is salutary to reflect on the role of law when it crosses the imaginary line between law and morality. If law is confined to a purely functional role, that is unproblematic, but, as soon as its focus shifts to the normative realm, it becomes contentious because unanimity is unattainable in a pluralistic society.

Of course, the $S D A$ was not the first occasion on which the federal government had sought to alter social norms in ways that challenged conservative religious beliefs by legislative fiat. The Family Law Act 1975 (Cth) is a notable example, and there are many others. The SDA was, however, widely believed to be revolutionary because of its potential to disrupt the prevailing social order. While many saw this as a social good, a vociferous minority was adamantly opposed.

\section{The Politics of Reform}

The 1970s was a distinctive period in Australian political history. The social liberalism associated with Gough Whitlam marked the beginning of a new era. There was a rejection of classical liberalism, moral conservatism and the 'British to the bootstraps' ideology of the Menzies years. The Whitlam era involved a dynamic period of law reform that included no-fault divorce, Aboriginal rights, environmental protection, free tertiary education and a range of other distributive justice policies associated with the modernisation of the Australian state. Law was seen as a positive force for change despite its past sins, and feminist activists wanted to play a central role in the transformation.

Social liberalism's concern with equity and the collective good underscored the starkness of the marked under-representation of women in many facets of public and economic life. A robust civil society enabled feminism in its many guises to emerge and establish itself as a political force for change. The Whitlam

8 Australian Bureau of Statistics, Year Book Australia 2006, Australian Bureau of Statistics, Canberra, 2007. This figure is taken from the 2001 Census.

9 For example, Members of the Board of the Wesley Mission Council v OV \& OW (No. 2) [2009] NSWADTAP 57. 
Government responded positively to the reform agenda. Its initiatives had been supported by the establishment of a formal role for feminist advisors within government bureaucracies, which gave rise to the Australian neologism the 'femocrat'. The functional and the normative came to be intimately intertwined under social liberalism.

The element of bipartisanship associated with the SDA puts paid to the suggestion that it was only the Australian Labor Party that favoured reform. It was Liberal Party policy to support the Bill after CEDAW was signed in Copenhagen in 1980 on behalf of Australia by Liberal MP R. J. Ellicott QC, although the convention was not ratified until the Labor Party came into office in 1983. Liberal MPs Ian Macphee and Peter Baume were among the staunchest supporters of the Bill. Sustained opposition emanated from the right wing of the Liberal Party, as well as the National Party. So passionate were the sentiments aroused by the Bill that it is credited with having caused a philosophical split within the Coalition. ${ }^{10}$ Maverick independent Senator Brian Harradine relentlessly campaigned against the Bill, zealously pursuing the issue of abortion, to which we will return.

Despite the efforts of feminist reform groups, such as the Women's Electoral Lobby (WEL), to pressure political parties to include issues of concern to women in their election platforms, there was a dearth of women in Parliament before International Women's Year, 1975. A record number of female candidates stood in the Australian federal election of $1983,{ }^{11}$ but the number of women elected remained minuscule, which meant that the SDA was debated in an overwhelmingly masculinist environment. Of the 125 members in the House of Representatives, there were only six women, all of whom were on the Labor side; in the Senate, there were 13 women and 51 men across all parties. Somewhat ironically in light of the substance of the $S D A$, women were still reliant on the good graces of men to alter entrenched gender norms.

In fact, only a minority of parliamentarians opposed the Bill, but those who did were loud in their denunciation of it. Opposition was galvanised by a deluge of petitions - almost 80000 opposing the legislation and a mere 1400 in favour. The ultra-conservative lobby groups that orchestrated the campaign against the Bill bombarded parliamentarians with literature, much of it misinformed, as well as lobbying them in person. The most assiduous of these groups was the curiously named Women Who Want to be Women (WWWW), founded and led by Babette Francis of Victoria. ${ }^{12}$

10 Philippa Hawker, 'A plain person's guide to that sex bill', Sydney Morning Herald, 6 October 1983, p. 38.

11 Marian Simms, "AA Woman's Place is in the House and in the Senate": Women and the 1983 Elections' in Marian Simms (ed.), Australian Women and the Political System, Longman Cheshire, Melbourne, 1984.

12 WWWW had close links with the National Party. Sawer reports that Francis ran as a National Party candidate in the 1984 federal election against a sitting Liberal who had supported the SDA. See Marian Sawer and Marian Simms, A Woman's Place: Women and Politics in Australia, Allen \& Unwin, Sydney, 1993, p. 226. 
Irene Webley published an insightful piece in 1983 analysing the role of WWWW in the context of the emergence of the New Right in Australia. ${ }^{13}$ Webley suggests that anti-feminist groups, such as WWWW, grew out of resentment over the fact that while government recognised women as a new political constituency, the territory had been commandeered by reformist feminist groups, such as WEL. ${ }^{14}$ New Right anti-feminist lobby groups, including WWWW and the Festival of Light, campaigned against the reformist initiatives, claiming to speak for the 'silent majority' - the women who 'chose' to remain at home and were in danger of being seduced by feminist rhetoric. The New Right lobby sought to abolish government consultative groups such as the National Women's Advisory Council, ${ }^{15}$ it attacked the validity of women's studies courses in universities and arranged for prominent US Moral Majority campaigners to come to Australia to lend their voices to the anti-progressive campaigns. Webley describes the New Right lobby as a loosely organised coalition with a platform that was essentially 'pro-life, pro-family and pro-Christian'. ${ }^{16}$

\section{Legislating for Social Change}

Susan Ryan introduced the first Sex Discrimination Bill as a Private Member's Bill in the Senate in 1981 but it was adjourned without a vote. The affirmative action provisions were particularly contentious and did not form part of the revised Bill, which the Labor Party introduced soon after coming into office in 1983. These provisions were set aside and, with the support of Prime Minister, Bob Hawke, became the subject of separate legislation-viz., Affirmative Action (Equal Employment for Women) Act 1986 (Cth).

Despite the hysteria surrounding the Sex Discrimination Bill, its aims were in fact extremely modest and unlikely to bring about the end of civilisation, as detractors predicted. Indeed, a similar model had been operating in New South Wales, Victoria and South Australia for some years. First of all, the ambit of the legislation was confined to certain areas of public and quasi-public life - viz., employment, education, goods and services, accommodation, land, clubs and the administration of Commonwealth laws and programs. Sexual harassment was expressly proscribed, albeit only in employment. Various exemptions were included, such as those pertaining to educational institutions established by religious bodies - a continuing source of contention on which we will elaborate.

13 Irene Webley, 'The New Right and Women Who Want to be Women in Australian Politics in the 1980s' (1983) 9(1/2) Hecate 7.

14 For a history of WEL, see Sawer, Making Women Count.

15 Lyndsay Connors, 'The Politics of the National Women's Advisory Council', in Simms, Australian Women and the Political System.

16 Webley, 'The New Right and Women Who Want to be Women in Australian Politics in the 1980s' 15. 
What is significant about the ambit of operation in light of the predicted demise of the family is that the private sphere qua family was immunised from scrutiny. No legislature has been brave enough to cross this line.

Second, the legislation was complaint based, not proactive, which meant that the onus was on an aggrieved individual, male or female, to lodge a complaint with the Human Rights Commission (HRC) alleging discrimination. ${ }^{17}$ The HRC would endeavour to conciliate the complaint in private. If this was unsuccessful, the HRC had the power to conduct a formal public hearing. At the hearing, the complainant would bear the onus of proving the discrimination according to the civil standard. The HRC did not have the power to make binding orders. Thus, even if the heroic complainant were successful at the HRC hearing, she could find herself confronted with a hearing de novo before the Federal Court in pursuit of binding orders. The debates contained no inkling of just how difficult this would prove to be.

The aim of the legislation was to effect equal opportunity for women to enable them to compete for jobs and other social goods on the same terms as men. There is no suggestion of preferential treatment; it was anticipated that the best person for the job would be appointed without regard to sex. The approach comported with the liberal principles of formal equality. ${ }^{18}$ While there was no express proposal to alter the workplace profile in order to secure substantive equality, it was nevertheless hoped that the resolution of each complaint would have a ripple effect within the community and contribute to the 'elimination' of discrimination in accordance with CEDAW. As argued elsewhere, however, this hope was naive as it is predicated on a belief that discrimination is finite and ignores the way that it is perennially being reconstituted and revived in an ever-changing socio-political context. ${ }^{19}$

Sex discrimination was only inferentially rendered unlawful by the Act (although the proscription of sexual harassment was explicit), as what constitutes discrimination is always contested and must be determined with regard to a particular social and temporal context. Despite limitations in the form of the $S D A$, it possessed great symbolic value. It might not have been able to change attitudes directly, but its proponents hoped that the ripples from each complaint would cause the deeply ingrained prejudice towards women in the public and quasi-public spheres to recede in time. The prospect of a utopian

17 The HRC became the Human Rights and Equal Opportunity Commission in 1986 and the Australian Human Rights Commission in 2009.

18 Margaret Thornton, The Liberal Promise: Anti-Discrimination Legislation in Australia, Oxford University Press, Melbourne, 1990, Ch. 1.

19 Margaret Thornton, 'Auditing the Sex Discrimination Act' in Marius Smith (ed.), Human Rights 2004: The Year in Review, Castan Centre for Human Rights Law, Monash University, Melbourne, 2005, pp. 21-56. 
society in which gender would have as much significance as eye colour, ${ }^{20}$ according to the assimilationist vision, filled the breasts of conservatives with a deep atavistic fear.

\section{The United Nations as Marxist Tyranny: Responses to CEDAW}

CEDAW was adopted by the UN General Assembly in $1979^{21}$ and came into force in 1981. The convention is powerfully worded: state parties 'condemn discrimination against women in all its forms' and agree to take 'all appropriate measures' for its elimination 'by all appropriate means and without delay' ${ }^{22} \mathrm{~A}$ very broad definition of discrimination is included to mean 'any distinction, exclusion or restriction made on the basis of $\mathrm{sex}^{\prime},{ }^{23}$ and the convention goes on to enumerate specific areas of private as well as public life on which state parties should focus. The overarching principle is one of effecting equality between men and women in all facets of political, social, economic and cultural life. ${ }^{24}$ To accelerate the achievement of this end, express reference is made to the acceptability of temporary special measures, ${ }^{25}$ which include affirmative or positive action. In addition, state parties are required to report regularly to a 23-member committee.

While CEDAW is potentially radical, Australia has interpreted its injunctions narrowly. ${ }^{26}$ First of all, the focus of the $S D A$ is on formal rather than substantive equality. Second, as already mentioned, a strict line of demarcation is maintained between public and private life. Third, the affirmative action provisions disappeared from the Bill at an early stage, which meant that the responsibility for initiating action and proving discrimination rested with individual complainants. Fourth, the Act is sex neutral not sex specific, as is the case with CEDAW - that is, the underlying presupposition of the SDA is that men and

\footnotetext{
20 Richard A. Wasserstrom, 'On Racism and Sexism' in Richard A. Wasserstrom (ed.), Today's Moral Problems, Third edition, Macmillan, New York, 1985, pp. 20-1.

21 Resolution 34/180, 18 December 1979.

22 CEDAW, Article 2.

23 CEDAW, Article 1.

24 The shift from a focus on protection and correction in earlier UN instruments to non-discrimination in CEDAW represented a significant change of direction. See Natalie Kaufman Hevener, 'An Analysis of Gender Based Treaty Law: Contemporary Developments in Historical Perspective' (1986) 8 Human Rights Quarterly 70. 25 CEDAW, Article 4.

26 Cf. Louise Chappell, 'Winding back Australian Women's Rights: Conventions, Contradictions and Conflicts' (2002) 37(3) Australian Journal of Political Science 475-88. For evaluation by former CEDAW Committee Chair Elizabeth Evatt, see Elizabeth Evatt, 'Eliminating Discrimination against Women: The Impact of the UN Convention' (1991-92) 18 Melbourne University Law Review 435.
} 
women are already similarly situated, a factor that heightens the burden of proof for complainants. Finally, the Australian Government reserved in two respects: the participation of women in armed combat and paid maternity leave. ${ }^{27}$

It might also be noted that the constitutionality of the $S D A$ did not depend on the external affairs power alone, but on a range of designated powers within the Constitution, including trade and commerce (s. 51[i]), banking (s. 51[xiii]), insurance (s. 51[xiv]), corporations (s. 51[xx]) and Territories (s. 122). Susan Ryan recounts how, with the help of Chris Ronalds, every constitutional power that could be used was included in the drafting of the Bill. ${ }^{28}$ Nevertheless, the entire focus of the attack in the course of the debates in regard to constitutionality is directed towards CEDAW and the use of the external affairs power. ${ }^{29}$

It is the preponderance of non-Western nation-states among the ratifying states that most disturbed the conservative parliamentarians. At the time of the debates, 55 countries had ratified CEDAW: eight from Africa, six from Asia, 11 from Eastern Europe, 20 from Latin America and 'only' 10 Western countries (including Australia). ${ }^{30}$ Underscoring the non-Anglo-centric orientation of CEDAW was the composition of the 23-member UN overseeing committee. Elected by secret ballot were four members from the Western Bloc, seven from the Eastern Bloc, six from Latin America, two from Africa and four from Asia. ${ }^{31}$ The chair was from Mongolia. ${ }^{32}$ The identity of the state parties and the composition of the committee underscored the suggestion that the anxiety of the conservative parliamentarians was not just because Australian sovereignty was being compromised by adherence to a UN treaty, but because of the xenophobia arising from the prominence of non-Western influences.

Such anxiety was expressed with recourse to Cold War rhetoric, which retained continuing resonance for conservatives and served as a trigger to reject the social progressivism represented by the Bill. The suggestion that the United Nations was a pretext for the spread of communism was articulated by Senator Ron

27 The reservation in respect to women in combat duties was partially withdrawn on 30 August 2000 (<http://treaties.un.org/doc/Publication/MTDSG/Volume\%20I/Chapter\%20IV/IV-8.en.pdf $>$ ). The Rudd Government enacted the Paid Parental Leave Act 2010 (Cth), which established a scheme to begin in January 2011.

28 Susan Ryan, Catching the Waves: Life in and out of Politics, HarperCollins, Sydney, 1999, p. 201.

29 Ian Macphee, Member for Balaclava (LP), said: 'No one would deny, for example, that the Bill should rest on the powers that are properly conferred on the Government in respect of interstate trade and commerce, corporations, financial corporations, or banking and insurance, but there is a great deal of disquiet about the use of the external affairs power as a safety net to provide residual validity in case the High Court should find that the more conventional heads of power were inadequate' (House Hansard, 5 March 1984, p. 502).

30 Margaret E. Galey, 'International Enforcement of Women's Rights' (1984) 6 Human Rights Quarterly 463, 483.

31 Ibid., 476.

32 Ibid. 
Boswell (LP), who, in a veiled reference to the chair of the CEDAW Committee, announced that ' $[\mathrm{t}]$ he women of Australia do not want legislation that is drafted by the public servants of Mongolia'. ${ }^{33}$

Parochial anxiety about Australia's increased participation on the international stage elicited resentment that 'we should be dragged by the nose to some international convention to be reminded of our derelictions in this country' ${ }^{34}$ Peter Drummond (LP) declared that many of the UN member states were 'ruled by Marxist tyrannies. Hypocrisy and humbug are their stock in trade.' He maintained that UN conventions were acceptable only to the extent that they expressed 'innocuous sentiments' and did not 'interfere with the lives of Australians':

The United Nations has some value in providing an international talking-shop, a safety valve, and some useful mechanisms and agencies. However, I think the people of Australia would be horrified to think of it as some kind of incipient world government, whose decrees and conventions are morally superior to the laws of this country. ${ }^{35}$

Resistance was also expressed as xenophobia, for, according to some senators, CEDAW was not relevant in Anglo-Celtic society, but 'makes perfectly good sense if it relates to the removal of social and legal repression of women as it exists in many Third World countries'. ${ }^{36}$ Senator Flo Bjelke-Petersen (NP) announced that the Bill would be more appropriate for 'the Middle East' ${ }^{37}$ - an ethnocentric sentiment echoed by future prime minister John Howard, who supported the Bill because 'amongst ethnic groups, there are incidences of discrimination and disadvantage against women which are not present within some of the more conservative or Anglo-Saxon elements of our society'. ${ }^{38}$ Such attitudes were not limited to the conservative side of politics - for example: Senator Michael Tate (ALP) stated that CEDAW was 'designed to liberate women in quite different cultures from our own who quite often are the slaves and victims of very chauvinistic societies' ${ }^{39}$

33 Senator Boswell (LP), Senate Hansard, 29 November 1983, p. 2963.

34 Mr Clarrie Millar, Member for Wide Bay (NP), House Hansard, 5 March 1984, p. 472.

35 Mr Peter Drummond, Member for Forrest (LP), House Hansard, 1 March 1984, p. 344.

36 Ibid.

37 Senator Flo Bjelke-Petersen (NP), Senate Hansard, 6 December 1983, p. 3335.

38 Hon. Mr John Howard, Member for Bennelong (LP), House Hansard, 7 March 1983, p. 671.

39 Senator Michael Tate (ALP), Senate Hansard, 21 October 1983, p. 1923. 


\section{Feminists in the House}

Often characterised by rhetorical flourishes that would be the envy of contemporary political speechwriters, the proposed legislation was condemned by conservatives, who alleged that it was evidence of the newly elected Hawke Labor Government's affiliation with communism. In a surprising display of familiarity with Marxism, Senator Boswell quoted Friedrich Engels as the source of the 'movement towards a unisex society' ${ }^{40}$ It was claimed the Bill was fundamentally flawed because it undermined traditional values and individual rights, which conservatives claimed were the hallmarks of a liberal democracy. The challenge to these principles was said to emanate chiefly from feminists on the left of the ALP whose recent arrival in the parliamentary chambers had unsettled the chauvinistic culture among conservatives in the Liberal/ National Coalition parties. According to Michael Hodgman (LP), the Bill was 'an appalling piece of legislation', which was promoted by 'arrogant minority pressure groups' to be 'inflicted upon the people of Australia by the Hawke socialist Government'. When announcing his intention to vote against the Bill, he said:

Whilst conceding that there are parts of the Bill with which I have no quarrel whatsoever, I have to say that the legislation as a whole is tainted with the pseudo-intellectualism of selfish and unrepresentative feminism and doctrinaire marxist-socialist precepts of contrived equality - defying even the laws of nature. This Bill, in so many ways, brings down upon itself the maxim reductio ad absurdum. It therefore does a grave disservice to the principle it espouses. ${ }^{41}$

The increased visibility of feminists in parliamentary politics and in senior positions in the public service in Australia from the mid-1970s generated bewilderment and antipathy among conservatives who feared their power would be diminished. Rather than extending equality of opportunity to women, the SDA was characterised as representing an attack on fundamental Christian values. The hostile response to progressive social change took the form of reactionary backlash, with denigrating - and often farcical - attacks on progressive women. Feminist politics was dismissed as an incomprehensible fad.

The Member for Franklin, Bruce Goodluck (LP), announced that he had conducted an investigation of WEL and concluded that most of the members

40 Senator Ron Boswell (LP), Senate Hansard, 29 November 1983, p. 2963, quoting The Origin of the Family (1884).

41 Hon. Mr Michael Hodgman, Member for Denison (LP), House Hansard, 5 March 1984, p. 489. 
were 'given-up Catholics'. While acknowledging that there were some women in the Liberal Party who supported the Bill, he flippantly dismissed women in the Labor Party because they advocated progressive political positions:

I have looked at the four women on the Government side. They are nice ladies... But they are all the same. They are always campaigning to save the cats, save the dogs and save the whales. They are anti-nuclear and pro-abortion... They are anti the flag and anti the dam...That is predominantly what Labor Party women are like. But they can talk; they are dashed good talkers. We have a few Liberal women who cross those lines and who are called trendy. But the majority of Liberal women are quiet and do not say much...I have nothing against Labor women personally but they all seem to take up this role and I am afraid that everybody is starting to think that that role is the norm. ${ }^{42}$

\section{Creating a Unisex Society}

The suggestion that the SDA was an inappropriate mechanism for liberaldemocratic capitalist states such as Australia functioned to augment a parallel argument that asserted that it threatened to destabilise traditional sex roles, reflecting a more general anxiety about the impact of second-wave feminism on social norms. Indeed, the $S D A$ was credited with significant transformative power; it was said to threaten to effect the eradication of sexual difference altogether. During the course of the parliamentary debates, the conservative think tank the Institute of Public Affairs published the opinion of a prominent paediatrician in which it was claimed that 'the basic philosophy of this Bill is to remove as far as possible all differences between men and women' ${ }^{43}$

Senator Pat Giles pointed out that it was beyond the government's power to 'legislate to eradicate gender differences', ${ }^{44}$ but the commitment in CEDAW to the elimination of sexism based on sex-role stereotypes ${ }^{45}$ was characterised by conservative lobby groups and parliamentarians as evidence of a desire to create a 'unisex society'. The use of the term 'unisex' — which had entered the lexicon to mean the provision of services to both men and women-demonstrates a

42 Mr Bruce Goodluck, Member for Franklin (LP), House Hansard, 2 March 1984, p. 391. Although Goodluck strongly opposed the SDA, he was subsequently reported as saying that he did not want his five daughters to be discriminated against. See Mary-Louise O'Callahan, 'Equality bill sparks a war cry', Sydney Morning Herald, 19 February 1986, p. 15.

43 Opinion of Dr Clair Isbister, published by the Institute of Public Affairs and cited by Senator Haines (Democrat), Senate Hansard, 21 October 1983, p. 1928.

44 Senator Pat Giles (ALP), Senate Hansard, 26 November 1983, p. 405.

45 Article 5(a) commits state parties '[t]o modify the social and cultural patterns of conduct of men and women, with a view to the elimination of prejudices and customary and all other practices which are based on the idea of the inferiority or the superiority of either of the sexes or on stereotyped roles for men and women'. 
fundamental misunderstanding of the concept of gender neutrality underlying liberal feminist claims to equal opportunity, suggesting a far more powerful role for law in subverting prevailing social norms.

Far from embracing gender neutrality, conservative politicians echoed the thesis of gender complementarity according to which women and men perform different social roles on the basis of their biological uniqueness. This thesis is entrenched within the Western intellectual tradition and can be traced back to Aristotle. ${ }^{46}$ Its crude socio-biology enabled a clear gender division between public and private spheres to be maintained. This was now being threatened, according to conservative politicians.

Ray Groom (LP) argued that '[t]he philosophy from which this Bill springs does not recognise any innate differences between male and female'; 'the sexes are not in competition but, according to the rules of nature, complement each other' ${ }^{47}$ Such claims were illustrated with reference to overstated examples of women performing non-traditional roles, such as 'digging drains, shearing sheep, slaughtering beasts or occupied as undertakers, [and] sawmill operators' ${ }^{48}$ Contrary to such images, Senator Archer announced that ' $[\mathrm{m}] \mathrm{en}$, by nature, are more likely to be leaders, providers and protectors. We can legislate all we like, but we will not change that... Why do women want to be like men, or men want to be like women... What has become wrong with being what nature provides?' ${ }^{49}$

The resistance provoked by the prospect of women working in male-dominated fields highlights the threatening presence of the feminine in the public sphere and its emasculating effect on men. The suggestion that the $S D A$ would facilitate the mass entry of women into archetypal 'masculine' areas of work-where resistance to the feminine remains pronounced - was, however, also a rhetorical device intended to undermine the legislation's appeal to the Western liberal principle of equality. It conjures up Cold War images of women in Eastern Bloc countries working in industries absent the trappings of Western notions of femininity. Senator Bjelke-Petersen described the removal of gender stereotypes as 'social engineering' 50 — not only exemplifying the attempt to associate the $S D A$ with totalitarianism, but also suggesting the insidious power of law to disrupt conventional norms of gender relations.

\footnotetext{
46 Londa Schiebinger, The Mind Has No Sex? Women in the Origins of Modern Science, Harvard University Press, Cambridge, Mass., 1989, pp. 216-22.

47 Hon. Mr Ray Groom, Member for Braddon (LP), House Hansard, 1 March 1984, p. 367.

48 Senator Brian Archer (LP), Senate Hansard, 8 November 1983, p. 2299.

49 Ibid.

50 Senator Flo Bjelke-Petersen (NP), Senate Hansard, 6 December 1983, p. 3335.
} 
Despite the significant feminist theoretical challenges to the nature/ culture dualism of sexual difference, ${ }^{51}$ biological determinism animated the parliamentary debates. According to Senator Archer, the proposed legislation would make it an offence to take into account the sexual characteristic of 'most ordinary, natural women', who are 'homely and caring...not wildly ambitious... not naturally dominating... and mostly inclined to avoid authority...by nature, more cautious and more considerate'.$^{52}$

By the early 1980s, women had entered the paid workforce in Australia in significant numbers, but participation was concentrated in the occupational categories of clerical, sales and services, as had been the case for most of the twentieth century. ${ }^{53}$ In these occupations, it is assumed that 'natural' feminine characteristics such as subservience and compassion are demanded. The feminisation of these traditional roles, particularly when part-time and/ or at junior levels, does not unduly disrupt the patriarchal construction of subordination in which full citizenship is withheld from women. As Pateman pointed out: "The civil right to "work" is still only half-heartedly acknowledged for women. Women in the workplace are still perceived primarily as wives and mothers, not workers.' ${ }^{54}$

Resistance to the $S D A$ reflected this perception, as we will go on to discuss.

\section{The Disintegration of the Patriarchal Family}

Undoubtedly, the most menacing ramification of the SDA was that it was bound to contribute to the disintegration of the patriarchal nuclear family. The Bill was described as an attack on 'the importance of the family as the fundamental unit of society, and our traditional Australian way of life'..$^{55}$ Innumerable petitions were tabled in both houses of parliament alleging that the commitment within CEDAW to the elimination of stereotyped roles for men and women ${ }^{56}$ was likely to contribute to 'further marriage insecurity and breakdown', as well as disrupting

\footnotetext{
51 For example, Simone de Beauvoir, The Second Sex, Translated and edited by H. M. Parshley, Four Square Books, New English Library, London, 1960; Sherry B. Ortner, 'Is Female to Male as Nature is to Culture?' in Michelle Zimbalist Rosaldo and Louise Lamphere (eds), Woman, Culture and Society, Stanford University Press, Calif., 1983.

52 Senator Brian Archer (LP), Senate Hansard, 8 November 1983, p. 2299.

53 Margaret Power, 'Women's Work is Never Done - by Men: A Socio-economic Model of Sex-typing in Occupations' (1975) 17 Journal of Industrial Relations 225.

54 Carole Pateman, The Disorder of Woman: Democracy, Feminism and Political Theory, Polity Press, Cambridge, 1989, p. 190.

55 Hon. Mr Michael Hodgman, Member for Denison(LP), House Hansard, 5 March 1984, p. 489.

56 Part III, Article 10(c) commits state parties to ' $[\mathrm{t}$ ] he elimination of any stereotyped concept of the roles of men and women at all levels and in all forms of education by encouraging coeducation and other types of education which will help to achieve this aim and, in particular, by the revision of textbooks and school programmes and the adaption of teaching methods'.
} 
traditional parental roles leading to 'emotional disturbances of childhood'. ${ }^{57}$ In the wake of second-wave feminism and no-fault divorce, reactionary responses crystallised in regard to the increasing instability of the patriarchal nuclear family. By the early 1980s, the introduction of no-fault divorce under the Family Law Act 1975, together with increasing numbers of single-parent families headed by women, had a significant impact on the constitution of the family. To counteract the disorder arising from 'unmanned' women usurping the proper role of the pater familias, conservative organisations - notably, WWWW - trenchantly advocated for the primacy of the heterosexual nuclear family. ${ }^{58} \mathrm{WWWW}$ was also supported by the wives of prominent conservative politicians, such as Margot Anthony, wife of the National Party leader, who argued that the $S D A$ would 'encourage the breakdown of the family unit' ${ }^{59}$

It was repeatedly alleged that the principle of non-discrimination enshrined in CEDAW imposed a requirement on women to reject their traditional role within the family. Senator Crichton-Browne (LP) claimed that the convention 'seeks to assert that many women who consider themselves to be both happy and equal in their roles as mothers and wives are not happy, and that the steps set out in the Convention requiring a change in their roles are necessary to make them equal'. He declared that ' $\mathrm{t}]$ he real intention and purpose of this legislation... is a not too subtle attempt to destroy the structure, the fabric, the values and the intrinsic role of the family unit which for centuries has been the foundation of our orderly and disciplined society and culture'. ${ }^{60}$

Ray Groom (LP) claimed that almost every provision in the convention 'attempts to encourage women to leave home and go into the workforce', but it 'is high time we did more to give proper support to the woman who chooses to remain at home to look after her family' ${ }^{61}$ Despite attempts by supporters of the Bill to make clear that neither CEDAW nor the SDA 'obliged anyone to enter the paid work force or to alter people's views of their responsibilities towards their spouses or children', ${ }^{62}$ the legislation was repeatedly said to force mothers out to work, with 'no choice...except for short maternity leave'. ${ }^{63}$

Women would lose their 'right to choose' to prioritise their role as wives and mothers over paid work. According to Senator Shirley Walters, it was 'quite

57 For example, petition tabled by Senator Sir John Carrick, Senate Hansard, 1 November 1983, p. 1976; petition tabled by Senators Button, Sir John Carrick and Collard, Senate Hansard, 2 November 1983, p. 2041. 58 WWWW, which has since changed its name to Endeavour Forum, continues to be active in lobbying governments on a range of issues. It claims to have been set up to 'counter feminism, defend the unborn and the traditional family' (<http://www.endeavourforum.org.au/>)

59 Jenny Cooke, 'Strong advice for Flo, Mrs Anthony', Sydney Morning Herald, 21 September 1983, p. 3.

60 Senator Noel Crichton-Browne (LP), Senate Hansard, 9 December 1983, p. 3628.

61 Hon. Mr Ray Groom (LP), Member for Braddon, House Hansard, 1 March 1984, p. 367.

62 Senator Peter Durack (LP), Senate Hansard, 21 October 1983, p. 1919.

63 Pamphlet distributed by WWWW, cited by Mr Leonard Keogh (ALP), Member for Bowman, House Hansard, 2 March 1984, p. 406. 
incorrect' that Australian women were 'paid less for equal work and equal time' because 'women choose different careers from men'. She claimed that the reason women earn less than men is because '[w] omen make choices. The facts prove that they choose to have a family...96.1 per cent of married women choose to have babies. Obviously they make it a greater priority than a career.' ${ }^{64}$

The use of the rhetoric of 'choice' resonates with contemporary debates over abortion - another issue that was tenaciously pursued, as we will discuss.

The emotive power of the mother-child relationship was not lost on opponents of the SDA, who made dire predictions that motherhood would become a 'second class calling or profession', leaving the state with the responsibility for the 'care and control of the child from infancy to maturity with the opportunity to mould its emotional life and its thinking' ${ }^{65}$ Rather than a progressive move that would facilitate the entry of women into the paid workforce, child care was described as 'a disgrace', where young children suffered maternal deprivation, 'their thumbs stuck in their mouths, all trying to rock themselves to sleep' ${ }^{66}$

In the face of such rhetoric, supporters of the legislation recognised the necessity of affirming the legislation's inability to effect significant changes in the structure and organisation of the traditional family. Senator Giles acknowledged that '[s]ome of the less palatable aspects of the family - its nuclear structure and its patriarchal dominance - are already in the process of modification'. Moreover, anti-discrimination legislation would 'lead to a greatly enhanced quality of relationships within that very resilient institution, the family'. ${ }^{67}$ Among members of the Coalition, significant divisions emerged. Senator Teague saw cause to table a statement outlining the Liberal Party's policy on the family as 'the fundamental and most important social and cohesive force in society' ${ }^{68}$ Nevertheless, the level of antipathy from some members, particularly the Nationals, resulted in the Coalition allowing a conscience vote on the SDA.

\section{Conscientious Objection: The Right to Discriminate}

The tension between law and morality was revealed most starkly in the proposal that emerged during debates that a conscientious objection clause be included in the $S D A$ itself in respect of its areas of operation. Such a clause would provide exemption where there are 'any conscientious beliefs, whether the grounds for

\footnotetext{
64 Senator Shirley Walters (LP), Senate Hansard, 29 November 1983, p. 2950.

65 Document signed by Dr Rendle-Short, Mrs Butler and Mrs Sully, tabled by Senator Baden Teague (LP), Senate Hansard, 29 November 1983, p. 2954.

66 Senator Austin Lewis (LP), Senate Hansard, 6 December 1983, p. 3329.

67 Senator Pat Giles (ALP), Senate Hansard, 8 November 1983, p. 2311.

68 Senator Baden Teague (LP), Senate Hansard, 29 November 1983, p. 2954.
} 
the beliefs are or are not of a religious character and whether the beliefs are or are not part of the doctrine of any religion' ${ }^{69}$ According to Evan Adermann (NP), such an exemption was necessary in a situation in which, for example, he decided to sell property and would otherwise be unable to prevent a prospective buyer who 'intended to institute a brothel, a witches' coven, a temple for Satan worship' if it could be 'alleged anywhere that sex, marital status or the like had any part in my decision' ${ }^{70} \mathrm{Mr}$ Groom announced: 'As I understand the Bill, it requires a person to decide between what his conscience tells him and what the law tells him. I think this is placing a very unfair pressure upon individuals in the community.' ${ }^{71}$

The government resisted pressure, however, to include a conscientious objection clause, because, as Senator Ryan pointed out, it would provide that 'one does have the right to discriminate if one's conscience tells one that women are inferior, unable to be trusted, or anything else'.$^{72}$

Nevertheless, the thin edge of the wedge was apparent, for the government was prepared to concede an exemption for church-run educational institutions to discriminate in employment on the grounds of sex, marital status or pregnancy, 'where the discrimination is in accordance with the doctrines of the religion or creed and the discrimination occurs in good faith... The discrimination itself has to flow from the ethos, the creed, the values, of that particular educational institution' ${ }^{73}$ The Opposition did not believe this went far enough-proposing an amendment to exempt non-denominational schools that were 'conducted in accordance with stated moral principles which are not, in fact, dictated by the teachings or beliefs of a particular religion' ${ }^{74}$ This amendment was defeated in committee. ${ }^{75}$ The exemption in favour of religious schools accords with the general practice of the secular state in deferring to religious freedom. The anomaly in the Australian context is that religious schools are not strictly 'private' as they are the recipients of substantial state funding. No regard was paid to this factor in the debates, although the Defence of Government Schools $(D O G S)$ case, in which state aid for private schools had been unsuccessfully challenged in the High Court, ${ }^{76}$ had been a matter of public controversy only a couple of years earlier.

69 Senator Brian Harradine (Ind.), Senate Hansard, 16 December 1983, p. 3994.

70 Mr Evan Adermann, Member for Fisher (NP), House Hansard, 5 March 1984, p. 485.

71 Hon. Mr Ray Groom, Member for Braddon (LP), House Hansard, 1 March 1984, p. 367.

72 Senator Susan Ryan (ALP), Senate Hansard, 16 December 1983, p. 3997.

73 Senator Michael Tate (ALP), Senate Hansard, 21 October 1983, p. 1923. Under the Sex Discrimination Act 1984 (s.

38), there is exemption in the area of employment, including contract workers, in situations where this is conducted 'in good faith in order to avoid injury to the religious susceptibilities of adherents of that religion or creed'.

74 Senator Peter Durack (LP), Senate Hansard, 29 November 1983, p. 2948. The Australian Parents' Council (representing private schools) also attacked the government for not going far enough. See Amanda Buckley,

'Parents criticise sex bill changes', Sydney Morning Herald, 13 October 1983, p. 5.

75 Amendment proposed by Hon. Mr Ian Macphee, Member for Balaclava (LP), House Hansard, 7 March 1984, p. 627.

76 A-G (Vic) Ex rel Black $v$ Commonwealth (1981) 146 CLR 559. 
Undoubtedly, the biggest 'red herring' of the SDA debate was the issue of abortion. ${ }^{77}$ Despite the fact that neither CEDAW nor the Bill made any reference to abortion - which hardly falls within the sex-neutral provision of goods and services - the prospect that the legislation could 'convert a woman's decision to have an abortion into a right to demand that abortion' was addressed in thousands of petitions and repeatedly raised in the parliamentary debates. Senator Ryan clearly explained that anti-discrimination legislation could not be used in this context because '[o]ne cannot say that it is discriminatory to refuse a man an abortion since in the nature of that service it is not available to be offered to a man' ${ }^{78}$ This was supported by legal advice to the Right to Life Association of Victoria. ${ }^{79}$ Nevertheless, as a result of Senator Harradine's relentless pursuit of the issue, ${ }^{80}$ an amendment was included to clarify concern that the Bill did not apply to the 'provision of services the nature of which is such that they can only be provided to members of one sex' ${ }^{81}$

The passage of the SDA represented the triumph of social liberalism in Australia. Far from persuading others through their rhetoric, Senator Harradine and those conservative Liberal and National Party members who opposed the Bill succeeded only in alienating their colleagues with their filibustering and hyperbolic claims. Similarly, groups such as WWWW vigorously garnered opposition to the SDA in the broader community, but the final votes suggest that they exercised little impact on the mainstream. In the Senate on 16 December 1983, there were 40 ayes and 12 noes; in the House of Representatives on 7 March 1984, there were 86 ayes and 26 noes. ${ }^{82}$ Susan Ryan noted in her autobiography that the SDA was probably the most useful thing she had done in her life. ${ }^{83}$

\section{Conclusion}

The tension between equality and liberty - the constituent elements of liberalism - is very clearly illustrated by the passage of the SDA and the subsequent backlash. ${ }^{84}$ Any attempt to implement policies of equality and distributive justice under social liberalism is likely to induce a sense of

\footnotetext{
77 Senator Susan Ryan (ALP), Senate Hansard, 16 December 1983, p. 3964.

78 Ibid., p. 3964; SDA, s. 32.

79 Advice provided by P. J. O'Callaghan (30 November 1983), tabled by Senator Michael Tate (ALP), Senate Hansard, 16 December 1983, p. 3987.

80 Concern was also expressed by Senator Austin Lewis (LP) (Senate Hansard, 6 December 1983, p. 3329)

and Senator Flo Bjelke-Petersen (NP) (Senate Hansard, 6 December 1983, p. 3335).

81 Senator Kathy Martin (LP), Senate Hansard, 16 December 1983, p. 3966.

82 Senate Hansard, 16 December 1983, p. 4011; House Hansard, 7 March 1984, p. 677.

83 Ryan, Catching the Waves, p. 243.

84 As Sawer shows, the retreat from EEO was not confined to the conservative political parties. See Marian Sawer, Sisters in Suits: Women and Public Policy in Australia, Allen \& Unwin, Sydney, 1990, pp. $212-26$.
} 
ressentiment $t^{85}$ among conservatives. As Wendy Brown argues, they feel that their freedom has been attenuated, which causes them to campaign against equality for increased liberty. ${ }^{86}$ When conservatism is in the ascendancy, egalitarianism contracts and the ressentiment of the left causes the pendulum to swing in the other direction.

The ressentiment of the right over social-liberal initiatives of all kinds, including the $S D A$, led to the fervent embrace of neo-liberalism within little more than a decade of the passage of the SDA. The feminist agenda quickly became passé within the wider community as the discourse of the market became the metanarrative of the millennial moment. An intimate liaison was effected between the state and the market. Although secularism was ostensibly in the ascendancy, the state's embrace of neo-conservatism allowed greater cognisance of and deference to religion. ${ }^{87}$

The category 'woman', which was central to the political power of the women's movement in the period leading up to the passage of the $S D A$, also began to disintegrate. Instead of the one-dimensional woman of feminist discourse, a more nuanced heteroglossic symbol emerged in which greater attention was paid to difference, particularly with regards to race, sexuality and disability. A notable manifestation of the phenomenon was the way women's studies courses began to disappear from the academy in favour of gender studies or diversity studies. With feminism no longer in the ascendancy, the neo-conservative disciplining gaze could be directed to the family in its traditional nuclear incarnation, together with sexuality and extramarital pregnancy.

The SDA signified a major rift between secularism and religion in terms of gender norms. The rift highlights the aporia between equality and liberty that is central to liberal theory. On the one hand, as Julian Rivers suggests, gender equality requires the 'complete androgynisation of law', ${ }^{88}$ which has profound moral consequences for understandings of sex and gender. On the other hand, freedom of religion is one of the manifestations of liberty, along with freedom of speech, property and the person, to say nothing of freedom of the market, which is accentuated by conservatism. The struggle over the androgynisation of law, which began with the $S D A$, has become the new site of struggle within liberalism. Rather than a focus on sex per se, attention has, however, subtly shifted to race, religion or age, so that the issues of sex, sexuality and

\footnotetext{
85 Nietzsche uses this term to capture the desire of a victim to retaliate by inflicting harm on the perpetrator in order that the victim might lessen his or her own pain. See Friedrich Nietzsche, On the Genealogy of Morals, Translated by W. Kaufman and R. J. Hollingdale, Vintage Books, New York, 1969, p. 127.

86 Wendy Brown, States of Injury: Power and Freedom in Late Modernity, Princeton University Press, NJ, 1995 , p. 67.

87 Marion Maddox, God Under Howard: The Rise of the Religious Right in Australian Politics, Allen \& Unwin, Sydney, 2005.

88 Julian Rivers, 'Law, religion and gender equality' (2007) 9 Ecclesiastical Law Journal 33, 50.
} 
marital status are occluded, other than in instances where corporeality is to the fore: sexual harassment, pregnancy and caring for children. This shift in the prioritisation of grounds instantiates the conservative orthodoxy that sex discrimination is now passé.

\section{Bibliography}

\section{Books and articles}

Brown, Wendy, States of Injury: Power and Freedom in Late Modernity, Princeton University Press, NJ, 1995.

Buckley, Amanda, 'Parents criticise sex bill changes', Sydney Morning Herald, 13 October 1983, p. 5.

Chappell, Louise, 'Winding Back Australian Women's Rights: Conventions, Contradictions and Conflicts' (2002) 37(3) Australian Journal of Political Science 475-88.

Connors, Lyndsay, 'The Politics of the National Women's Advisory Council' in Marian Simms (ed.), Australian Women and the Political System, Longman Cheshire, Melbourne, 1984.

Cooke, Jenny, 'Strong advice for Flo, Mrs Anthony', Sydney Morning Herald, 21 September 1983, p. 3.

de Beauvoir, Simone, The Second Sex, Translated and edited by H. M. Parshley, Four Square Books, New English Library, London, 1960.

Evatt, Elizabeth, 'Eliminating Discrimination Against Women: The Impact of the UN Convention' (1991-92) 18 Melbourne University Law Review 435.

Galey, Margaret E., 'International Enforcement of Women's Rights' (1984) 6 Human Rights Quarterly 463.

Hawker, Philippa, 'A plain person's guide to that sex bill', Sydney Morning Herald, 6 October 1983, p. 38.

Hevener, Natalie Kaufman, 'An Analysis of Gender Based Treaty Law: Contemporary Developments in Historical Perspective' (1986) 8 Human Rights Quarterly 70.

Maddox, Marion, God Under Howard: The Rise of the Religious Right in Australian Politics, Allen \& Unwin, Sydney, 2005. 
Nietzsche, Friedrich, On the Genealogy of Morals, Translated by W. Kaufman and R. J. Hollingdale, Vintage Books, New York, 1969.

O'Callahan, Mary-Louise, 'Equality bill sparks a war cry', Sydney Morning Herald, 19 February 1986, p. 15.

Ortner, Sherry B., 'Is Female to Male as Nature is to Culture?' in Michelle Zimbalist Rosaldo and Louise Lamphere (eds), Woman, Culture and Society, Stanford University Press, Calif., 1983.

Parkinson, Patrick, Christian Concerns with the Charter of Rights, Paper presented at Cultural and Religious Freedom under a Bill of Rights Conference, Canberra, 2009.

Pateman, Carole, The Disorder of Woman: Democracy, Feminism and Political Theory, Polity Press, Cambridge, UK, 1989.

Power, Margaret, 'Women's Work is Never Done-by Men: A Socio-economic Model of Sex-typing in Occupations' (1975) 17 Journal of Industrial Relations 225.

Rivers, Julian, 'Law, Religion and Gender Equality' (2007) 9 Ecclesiastical Law Journal 33.

Ryan, Susan, Catching the Waves: Life in and out of Politics, HarperCollins, Sydney, 1999.

Sawer, Marian, Sisters in Suits: Women and Public Policy in Australia, Allen \& Unwin, Sydney, 1990.

Sawer, Marian and Simms, Marian, A Woman's Place: Women and Politics in Australia, Allen \& Unwin, Sydney, 1993.

Sawer, Marian with Radford, Gail, Making Women Count: A History of the Women's Electoral Lobby in Australia, UNSW Press, Sydney, 2008.

Schiebinger, Londa, The Mind Has No Sex? Women in the Origins of Modern Science, Harvard University Press, Cambridge, Mass., 1989.

Simms, Marian, "A Woman's Place is in the House and in the Senate": Women and the 1983 Elections' in Marian Simms (ed.), Australian Women and the Political System, Longman Cheshire, Melbourne, 1984.

Thornton, Margaret, The Liberal Promise: Anti-Discrimination Legislation in Australia, Oxford University Press, Melbourne, 1990. 
Thornton, Margaret, 'Auditing the Sex Discrimination Act' in Marius Smith (ed.), Human Rights 2004: The Year in Review, Castan Centre for Human Rights Law, Monash University, Melbourne, 2005.

Wasserstrom, Richard A., 'On Racism and Sexism' in Richard A. Wasserstrom (ed.), Today's Moral Problems, Third edition, Macmillan, New York, 1985.

Webley, Irene, 'The New Right and Women Who Want to be Women in Australian Politics in the 1980s' (1983) 9(1/2) Hecate 7.

\section{Legislation}

Racial Discrimination Act 1975 (Cth)

Sex Discrimination Act 1984 (Cth)

\section{Cases}

A-G (Vic) Ex rel Black v Commonwealth (1981) 146 CLR 559 (DOGS case)

Commonwealth $v$ Queensland (Queen of Queensland) (1975) 134 CLR 298

Commonwealth v Tasmania (1983) 158 CLR 1 (Tasmanian Dams)

Koowarta v Bjelke-Petersen (1982) 153 CLR 168

Members of the Board of the Wesley Mission Council v OV \& OW (No. 2) [2009] NSWADTAP 57

\section{Reports and miscellaneous primary sources}

Commonwealth of Australia, National Human Rights Consultation Report, Commonwealth of Australia, Canberra, 2009 [Brennan Report].

Parliament of Australia, Hansard: House of Representatives, Parliament of Australia, Canberra, 1983-84.

Parliament of Australia, Hansard: Senate, Parliament of Australia, Canberra, 1983-84.

United Nations Convention on the Elimination of All Forms of Discrimination Against Women, United Nations, New York.

United Nations Convention on the Elimination of All Forms of Racial Discrimination, United Nations, New York. 